ПРИЛОЗИ, Одделение за природно-математички и биотехнички науки, МАНУ, том 38, бр. 1, стр. 105-108 (2017)

CONTRIBUTIONS, Section of Natural, Mathematical and Biotechnical Sciences, MASA, Vol. 38, No. 1, pp. 105-108 (2017)

Received: December 29, 2016

ISSN 1857-9027

Accepted: March 3, 2017

e-ISSN 1857-9949

UDC: 003.29:004.43

DOI:10.20903/csnmbs.masa.2017.38.1.106

Short communication

\title{
THE ROLE OF WHITESPACE IN NOTICING IN SCIENTIFIC DIAGRAMS`
}

\author{
John Oversby \\ Science Education Futures, Reading, UK \\ e-mail: oversby61@gmail.com
}

Scientic diagrams are one of the tools of explanation, alongside text. The paper is a part of research on the role of diagrams in learning, here focusing on what is known as whitespace. Whitespace, which is not always white, is often seen as empty space, that is space without content. However, many diagrams have active whitespace, such the green background in safety diagrams which indicates action to be taken, and is a positive colour. Some have red 'whitespace' indicating the danger of undertaking an action. These all promote 'noticing', that is, drawing features to the observers' attention as part of the diagram purpose. The paper explores two clear examples on safety diagrams (signs) and one where observers were unclear about what was whitespace and what was active content.

Key words: scientic diagrams; whitespace; empty space

\section{INTRODUCTION}

The role of diagrams in learning in science education is too often second place to text (words), even to the point of being central and dominant in many external assessment programmes. The PALAVA teacher researcher group (www.palava.wikispaces.com), physically located in the UK but having a virtual international membership, has been engaged in investigating representations (models) in science education for two decades. More recently PALAVA has targeted diagrams in science education. Our aims have been:

1. To characterise the distinguishing features of scientific explanatory and descriptive diagrams, as separate from the general category of illustrations and graphs;

2. To explore what observers notice in diagrams and, concurrently, develop the role of the Think Aloud Protocol as an investigative tool (e.g. Topsakal and Oversby 2012a, 2012b and 2013). By notice, we specifically refer to an active form of seeing that clarifies which features attract attention in the context of scientific explanation. The Think Aloud Protocol has been designed to probe tacit thinking by asking participants to share aloud this thinking with the researcher. Thinking Aloud contemporaneously seems to slow down the thinking processes, and often to stray into episodes of explanation, but is one of the best methods of exposing thinking. Recalled and stimulated Thinking Aloud Protocols are also used but can be subject to both forgetfulness and to rationalisation of immediate thinking.

3. To explore construction of diagrams by individuals and groups for creating a scientific explanation or description. PALAVA has continued to use the Think Aloud Protocol in these studies.

4. To investigate the role of tactile diagrams

I will use examples to indicate some of the issues involved. Much of the written material around whitespace comes from marketing and design contexts. We have so much to learn from other disciplines.

\section{The Chinese Food Guide Pagoda}

The Chinese Food Guide Pagoda (Food and Agriculture Organisation of The United Nations, 2007) below serves as a suitable diagram to demon- 
strate a typical diagram used in science education. It has elements of icons (pagoda shapes and a male person), diagrams of different kinds of food, and significant quantities of text, alongside important matters such as location.

Apart from the active components there is much space that is simply there but intended to be ignored. Traditionally, this space was white (the colour of the paper) and was termed whitespace. It indicates a part of a page that is not covered by print or graphic matter. However, in the food pagoda a part that is intended to be un-noticed is grey so that we can say that the whitespace is grey. In this article, 'noticing' is used in the sense of attracting definite attention, worthy of letting the mind dwell on its meaning in some way. The food pagoda diagram has other areas that I believe are not intended to be noticed. Each of the four pagoda levels has a background of a different colour. These do not appear to be significant, so could be treated as whitespace.

\section{(1) Food Guide Pagoda}

\section{Chinese Food Guide Pagoda(2016)}

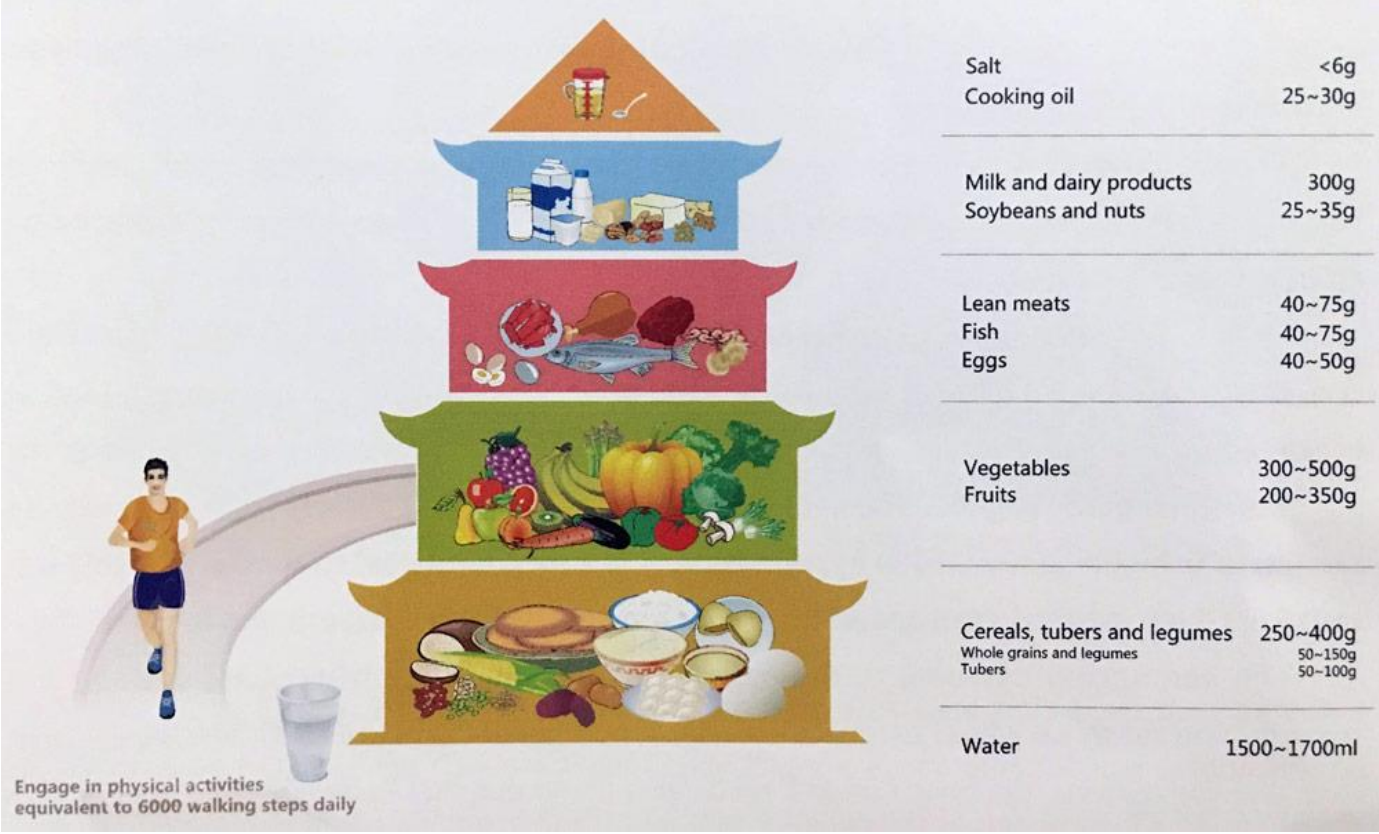

\section{Active whitespace - safety signs that are diagrams}

The ubiquitous safety sign indicating where to go in the event of a fire breaking out has a background of green (right). The green is not only whitespace but is a positive statement to carry out an action at a specific time. A group of science teacher educators 'noticed' the text, the arrow, the icon of the person, and the door, as prominent features. The green space was a sub-conscious feature. There is a green icon, the person, that is intended to be noticed. So, perhaps there are two kinds of green in this diagram. One is the green of an icon, and the other green is active whitespace.

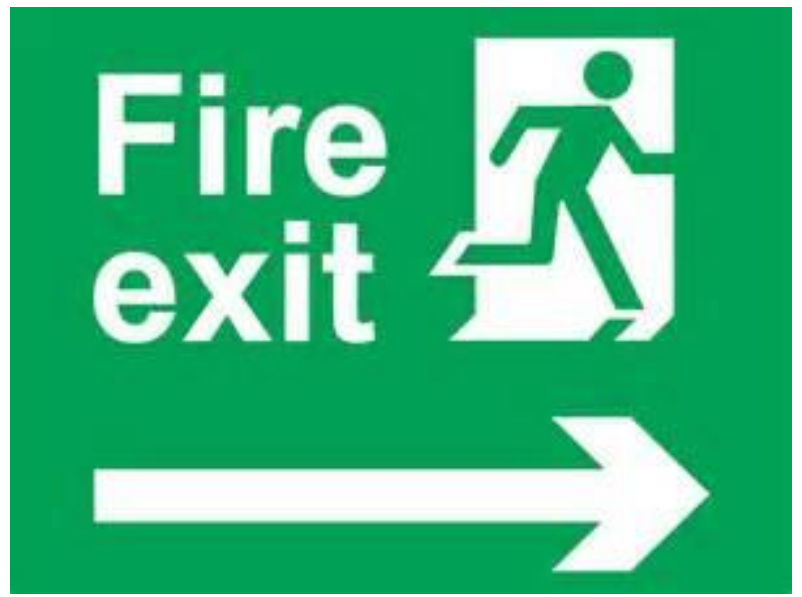

The second safety sign (below) is also one that has active whitespace, red. This indicates danger. 

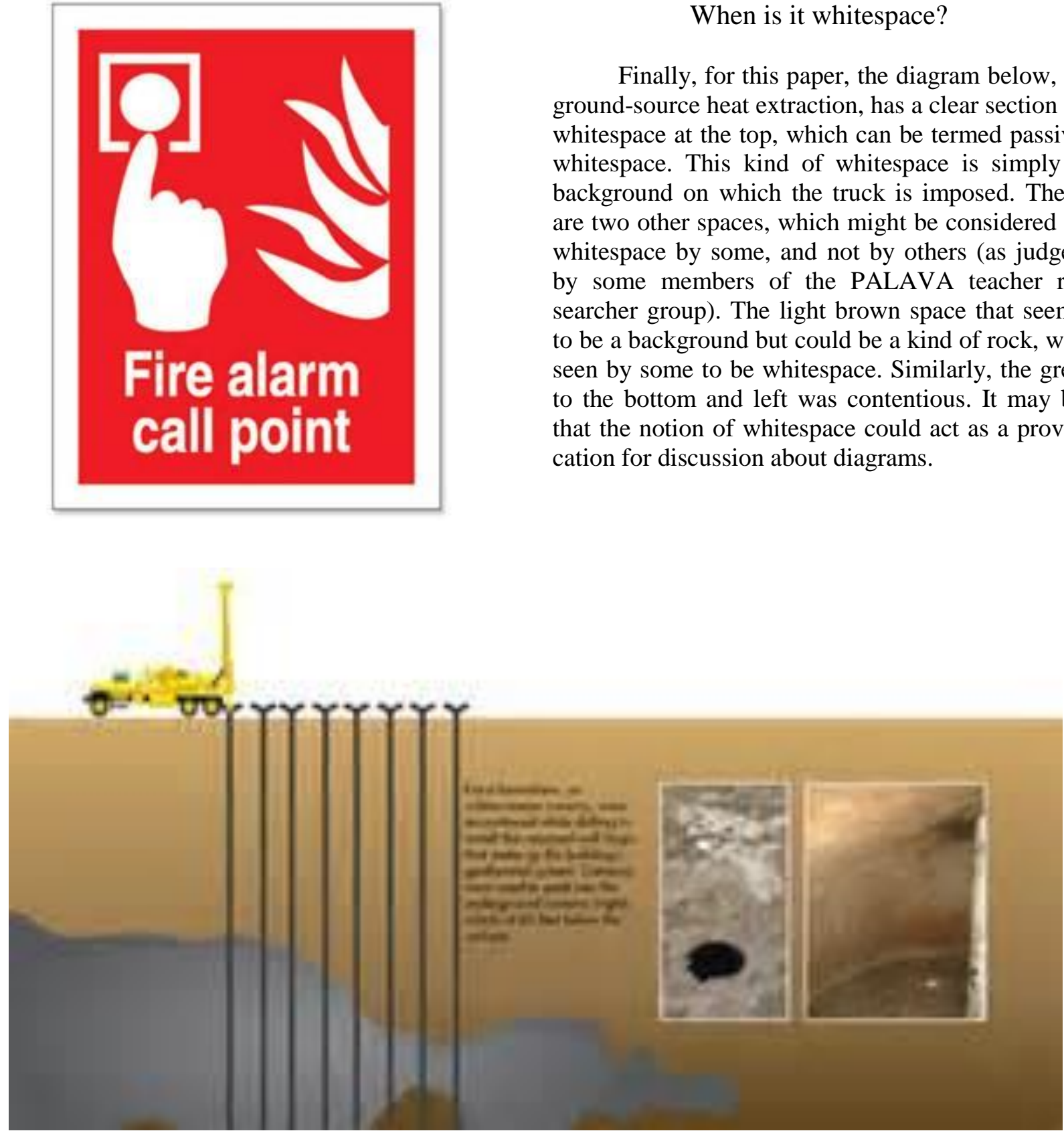

\section{When is it whitespace?}

Finally, for this paper, the diagram below, of ground-source heat extraction, has a clear section of whitespace at the top, which can be termed passive whitespace. This kind of whitespace is simply a background on which the truck is imposed. There are two other spaces, which might be considered as whitespace by some, and not by others (as judged by some members of the PALAVA teacher researcher group). The light brown space that seems to be a background but could be a kind of rock, was seen by some to be whitespace. Similarly, the grey to the bottom and left was contentious. It may be that the notion of whitespace could act as a provocation for discussion about diagrams.

\section{CONCLUSION}

In this paper, I have attempted to illustrate some research thinking about diagrams, particularly about whitespace in diagrams. Firstly, whitespace is not so obvious, as intended, but when it is recognised as a significant part of a diagram, it may help us to understand the diagram better. Secondly, whitespace can be contentious, with the resulting arguments enabling researchers to drill deeper into the issue.

The whitespace research may eventually lead into a clear typology of various kinds of space in diagrams that could help in data analysis. At this stage, initial thinking is that macro-whitespace (space that is not simply the gap between text letters or lines of text) may be of three kinds:

- Whitespace that is non-contentious to most observers, being simply space that is not occupied by any content. Some designers call this passive whitespace.

- Whitespace that is not occupied by content but influences the observer, such as the green in the exit sign which is a go-colour. Designers often call this active whitespace.

- Whitespace that seems to be contentious, such as the grey and brown spaces in the last diagram. Using the Think Aloud Protocol on this kind of whitespace may be valuable in unearthing the subtle ways in which a diagram can be interpreted. 


\section{REFERENCES}

[1] Topsakal, ÜU., Oversby, J., Turkish Student Teachers' Ideas About Diagrams of a Flower and a Plant Cell, Journal of Biological Education, 46, (2012 a), pp. 81-92.

[2] Topsakal UU \& Oversby J, Chromosome, DNA and Gene Diagrams According to the Turkish Student Teachers, Cypriot Journal of Educational Sciences, 7 (2012b), pp. 378-383.
[3] Topsakal, ÜU., Oversby, J., What do scientist and non-scientist teachers notice about biology diagrams?, Journal of Biological Education, 47 (2013), pp. 21-28.

[4] Food and Agriculture Organisation of The United Nations, (2007) Food-based dietary guidelines China accessed at http://www.fao.org/nutrition/education/food-based-dietary-guidelines/regions/ countries/china/en/ 09 December 2016.

\title{
УЛОГАТА НА БЕЛИОТ ПРОСТОР (WНІТЕSРАСЕ) ВО КРЕИРАЊЕ НАУЧНИ ДИЈАГРАМИ
}

\author{
John Oversby
}

Science Education Futures, Reading, UK

Научните дијаграми се едни од алатките за објаснување на текстот. Овој труд е дел од истражувањата за улогата на дијаграмите при учењето, со посебен осврт, во овој случај, на тоа што претставува белиот простор (whitespace). Белиот простор, којшто не секогаш е бел, често се гледа како празен простор, што претставува простор без содржина. Меѓутоа, многу дијаграми имаат активен бел простор, како што е, на пример, зелена позадина во сигурносни дијаграми која индицира преземање на акција и претставува позитивна боја. Некои имаат црвен 'бел простор' кој укажува на опасност од преземање на акција. Сите тие промовираат некој вид предупредување, односно сликовни карактеристики за привлекување на внимнието на набљудувачите како дел од целта на дијаграмот. Трудов истражува два чисти примера на сигурносни дијаграми и еден каде на набљудувачите не им било јасно значењето на белиот простор, односно активната содржина.

Клучни зборови: научни дијаграми; бел простор (whitespace); празен простор 